\title{
Start-ups, Innovation and Knowledge Spillovers
}

\author{
David Bruce Audretsch ${ }^{1} \cdot$ Maksim Belitski ${ }^{2,3}$ (D) Rosa Caiazza $^{4}$
}

Accepted: 13 January 2021 / Published online: 4 February 2021

(C) The Author(s) 2021

\begin{abstract}
The knowledge spillover theory of entrepreneurship (KSTE) seeks to explain the mechanisms of how uncommercialized knowledge can be turned into new to market products. This paper uses a large unbalanced panel of 16,542 UK firms constructed from six consecutive waves of a community innovation survey and annual business registry survey during 2002-2014 to test the differences in the returns to knowledge spillover for innovation between start-ups and incumbent firms. The theoretical, managerial, and policy implications of the study are discussed.
\end{abstract}

Keywords Start-ups; innovation; institutions $\cdot$ Knowledge collaboration · Knowledge spillover

JEL Classification $\mathrm{L} 25 \cdot \mathrm{L} 26 \cdot \mathrm{O} 31 \cdot \mathrm{O} 33$

\section{Introduction}

Innovation in start-ups, some of which are entrepreneurial firms, is shaped by investment in R\&D (Audretsch and Link 2019c) but also by the investments of external partners (Fritsch and Wyrwich 2018). A compelling body of entrepreneurship research has found that investments in knowledge from other firms and public organizations spillover (Jaffe et al. 1993; Audretsch and Link 2019a) to enhance firms' performance (Link and Rees 1990; Audretsch and Belitski 2020a). The knowledge spillover theory of entrepreneurship

Maksim Belitski

m.belitski@reading.ac.uk; mbelitski@groupe-igs.fr

David Bruce Audretsch

daudrets@indiana.edu

Rosa Caiazza

rosa.caiazza@uniparthenope.it

1 Ameritech Chair of Economic Development, Institute for Development Strategies, Bloomington, USA

2 ICD Business School, Groupe-IGS, via Alexandre Parodi, 12, Paris, France

3 Henley Business school, University of Reading, Whiteknights, Reading RG6 6UD, UK

4 Parthenope University of Naples, Via Generale Parisi 13, 80132 Naples, Italy 
(KSTE) illuminates an important entrepreneurial opportunity source by using commercializable third-party information (Acs et al. 2009; Agarwal et al. 2007, 2010). The KSTE assumes two important components: knowledge spillovers emanating from incomplete excludability of knowledge (Belitski et al. 2019) and the role of knowledge filters, which may either impede or facilitate knowledge transfer (Audretsch and Keilbach 2007, 2008; Audretsch et al. 2020).

While knowledge spillover cannot be fully exploited due to knowledge filter (Shu et al. 2014) entrepreneurial firms engage in other forms of active collaboration with external partners (Van Beers and Zand 2014; Baker et al. 2016) and invest in their own R\&D in order to increase absorptive capacity (Spithoven et al. 2010; Denicolai et al. 2016; Roper et al. 2017) and learn new skills (Khalil and Belitski 2020).

Although the entrepreneurial opportunities illustrated in the KSTE are realized through knowledge transfer from the third-party firms, it remains on the knowledge frontier what external sources needed to be combined to generate knowledge spillover and firm innovation (Block et al. 2013; Audretsch and Belitski 2019) In addition to substantial crosscountry and regional level research (Audretsch and Lehmann 2005; Audretsch et al. 2006; Audretsch and Belitski 2013) there is a paucity of knowledge at the firm level of analysis (Short et al. 2009; Shu et al. 2014; Bloom et al. 2013; Audretsch and Link 2019b, c; Audretsch et al. 2019).

Prior research argued that small firms benefit to a greater extent from knowledge spillover than larger firms (Audretsch and Belitski 2013; Braunerhjelm et al. 2010, 2018) with limited evidence on the role that knowledge spillover plays in innovation in newly established firms (start-ups) (Audretsch and Link 2019c).

In addition, a compelling body of entrepreneurship literature has inadequately addressed the origins of the KSTE and the potential outcomes of knowledge spillover-new firm creation, while new product creation in entrepreneurial firms has been neglected (Delmar et al. 2011; Belitski et al. 2019; Estrin et al. 2020). This study aims to bridge these gaps. Finally, due to its theoretical origin, the KSTE confines from incorporating important firmlevel characteristics into its framework, and in particular those related to other forms of knowledge collaboration (customers, suppliers, universities, competitors) and the types of innovation outcomes (Block et al. 2013).

Our paper links the KSTE (Acs et al. 2009) and entrepreneurship literature (Agarwal et al. 2007) to open innovation and knowledge transfer research using various origins of knowledge spillover to predict innovation performance in the most innovative UK firms (Ketchen et al. 2007; Eckhardt et al. 2018; Sauermann 2018).

In this study, we distinguish between different sources of external knowledge such as information available through technical and industrial standards, patents, conferences and trade fairs, and professional and industry associations that constitute the knowledge spillover for both incumbent and start-ups how knowledge spillover can be effectively commercialized. Based upon the KSTE, we hypothesize that an increase in knowledge spillover facilitates innovation performance in start-ups to a greater extent than incumbent firms. Incumbent firms, even if they recognize such opportunities, can be more focused on their core business and internal R\&D, which in addition to high uncertainty and risk associated with external knowledge, leads to the limited use of external knowledge. Innovative startups are more efficient in turning uncommercialized external information into new-to-themarket knowledge and new products leading latent forms of entrepreneurship to emerge (Acs and Audretsch 1990; Caiazza et al. 2020).

Our observation unit is a firm rather than a country or region (Audretsch and Caiazza 2016). We use an unbalanced panel dataset covering the innovation activity of 16,542 
UK firms constructed from six consecutive waves of a community innovation survey and annual business registry survey during 2002-2014. The results clearly show that start-ups, measured as the firms of small size at incorporation (up to 49 employees), are not subsidiaries of a larger firm and up to 7 years since incorporation over-perform incumbent firms in returns knowledge spillover. This finding is precisely what the KSTE and prior entrepreneurship research can predict.

This paper contributes to open innovation and knowledge transfer literature (Link and Scott 2011, 2019). First, by demonstrating that knowledge spillovers, as well as knowledge collaboration with external partners and internal investment in $\mathrm{R} \& \mathrm{D}$, facilitate innovation performance using data on the most innovative UK firms. One standard deviation in knowledge spillover increases new to market product sales by at least 10 percent, which means adding on average $0.5 \%$ to new product sales. Second, by emphasizing that information from external sources as conferences, trade fairs or exhibitions, professional and industry associations, technical, industry or service standards, scientific journals and trade/technical publication is important but overlooked, innovation input or knowledge-based mechanisms from research, scientific laboratories, industry and firms (Link and Scott 2019, 2020) as powerful as an investment in internal knowledge (Cohen and Levinthal 1989).

The next section briefly reviews the main literature and develops our research hypotheses. The data and empirical methodology are described in Sect. 3, while the results are discussed in Sect. 4. Section 5 discusses the theoretical, managerial, and policy implications of the study and future research.

\section{Theoretical framework}

\subsection{The Knowledge spillover theory of entrepreneurship}

Entrepreneurship is conceptualized in strategic terms as opportunity recognition (discovered or created), mobilization of resources to exploit opportunities (Shane and Venkataraman 2000), and economic development (Audretsch et al. 2015). These different aspects of entrepreneurship are all important. It could happen that despite such opportunities exist or are created; other actors cannot identify them. It could also happen that some actors recognize such resources but are unable to take the risk to exploit them. Thus, it becomes important to identify the source of such opportunities and why some actors couch them while others do not.

The KSTE (Acs et al. 2009) identified the source of such opportunities with knowledge spillovers, called endogenous entrepreneurship. Spillovers were first introduced earlier by Marshall (1890) as arising from agglomeration and were modeled by Arrow (1962) due to learning by doing. The evolution of endogenous growth theory (Romer 1986; Audretsch and Keilbach 2007; Acs et al. 2009) explicitly introduced knowledge spillovers into an endogenous growth model and the innovation literature, in empirical studies on knowledge spillovers by Anselin et al. (1997), Acs and Varga (2005), Keller (2002), Hall et al. (2013) and Roper et al. (2017). Due to the knowledge incomplete excludability (Audretsch and Belitski 2013), knowledge spills over so that the producers of knowledge cannot appropriate the entire value themselves (Foss et al. 2008).

Unlike knowledge collaboration, which is a rather active form of cooperation, recent studies have discussed knowledge spillovers as a form of the implicit or passive form of 
collaboration (Giovannetti and Piga 2017), where knowledge transfers cannot be observed directly between two agents (Audretsch and Caiazza 2016; Toms et al. 2020).

The information sources for knowledge spillovers are usually located in public domains and depend on a firm's ability to create information flows from the public pool of knowledge, such as patents, publications, and technical and industrial associations (Cassiman and Veugelers 2002; Audretsch et al. 2019; Link et al. 2019). These sources include information available in open or restricted access at the specialist conferences and events, exhibitions, participation in professional and industry associations, technical, industry or service standards, scientific journals, and trade/technical publications (Delmar et al. 2011; Short et al. 2009). Information within the public domain is openly available and does not require any direct interaction between the knowledge receiver and knowledge producer (Audretsch et al. 2006; West and Bogers 2014). Firms attempt to maximize the benefits of knowledge spillovers for innovation by increasing knowledge inflows and reducing outgoing knowledge outflows (Agarwal et al. 2007).

Following the KSTE perspective, we argue that knowledge spillovers create new entrepreneurial opportunities that not all existing actors can see. We also assume that knowledge filter related to the firm's own investment in $R \& D$, uncertainty, and risk as well as appropriability of new knowledge limit scalable exploitation of innovation by incumbent firms compared to start-ups.

\subsection{Knowledge spill-overs and innovation in start-ups and incumbent firms}

The common assumption is that firms will automatically benefit from knowledge spillover (Acs et al. 2009; Audretsch and Link 2019c). There are three issues to be discussed.

First, the extant literature addresses the potential downside of knowledge spillovers, especially for external partners of new ventures (Newbert and Tornikoski 2011; Nason et al. 2019). Incumbent firms are strategically focused on the core business that already exposes them to market uncertainty. They would experience a higher risk associated with knowledge collaboration with start-up firms, especially new ventures often in asymmetrical power relationships with external partners and lack resources. Theoretically and empirically, this may also imply the different abilities of start-ups and incumbent firms to appropriate knowledge outputs and use them for new product creation.

Second, the link between knowledge spillover and innovation is indirect (Audretsch and Belitski 2020b). For example, the literature suggests that entrepreneurship increases economic output by facilitating the commercialization of knowledge, but this link has not been analyzed in detail, and no distinction has been made between different types of firms (Block et al. 2013; Shu et al. 2014).

Third, the mechanism that turns knowledge into innovation is not automatic. The commercialization of knowledge includes efforts such as financing product development and market research. The outcome of this process is uncertain and risky and requires the risktaking behavior of entrepreneurs. Incumbents are already exposed to their core business risk and would not be interested in taking more innovations risks. Start-ups are considered different from incumbent firms because they are believed to have an above-average level of willingness to take risks (Kihlstrom and Laffont 1979) and have a high tolerance to ambiguity (Foss et al. 2008).

Risk can be calculated by incumbent firms before knowledge creation and turned into the cost to be insured. Incumbent firms are exposed to the uncertainty of existing business and would not be interested in supporting the risk of innovation evaluating costs more than 
revenue. As start-ups also lack resources, they will embrace uncertainty as entrepreneurs who lead start-ups are believed to be gifted with above-average perceptive talents relates to the exercise of judgment in the making of decisions on the use of knowledge spillover. Entrepreneurs are better at judging the opportunity and pick up information from different sources, which can be turned into innovation. Therefore several reasons can explain why start-ups are an efficient conduit in turning knowledge spillover into innovation as (1) innovative start-ups exhibit higher capital and other resource constraints (Acs and Audretsch 1990; Bradley et al. 2012) and they require external sources of knowledge, (2) they are more alert to market opportunities (Shane and Venkataraman 2000), than incumbent firms. Sufficient resources and investment in R\&D by incumbents will prevent them from risktaking behavior and experimenting with knowledge, increasing the attractiveness of exploring external knowledge for start-ups. Thus, we hypothesize:

Knowledge spillovers have a greater effect on innovation performance in start-ups than incumbent firms.

Our conceptual model is introduced in Fig. 1.

\section{Data and method}

\subsection{Sample}

We use an unbalanced panel dataset covering the innovation activity of 16,542 UK firms constructed from six consecutive waves of a community innovation survey (UKIS) and Business Structure Database (BSD) known as Business Register during 2002-2014. When initially matched, the sample size was 89,518 observations. We collected and matched the BSD data to the initial year of the UKIS for 2002, 2004, 2006, 2008, 2010 and 2012. The BSD includes firm legal status, ownership (foreign or national firm), alliance information (firm belongs to a larger enterprise network), export, turnover, employment, the industry at 5 -digit level and a firm location by the postcode. UKIS includes innovation input and output data, barriers to innovation, innovation mechanisms.

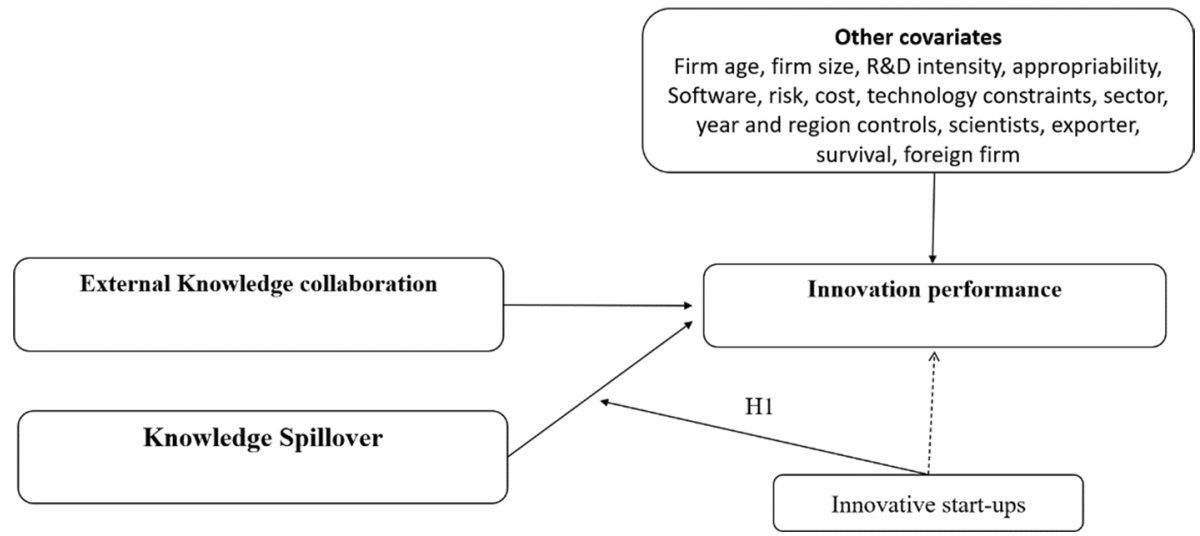

Fig. 1 The conceptual model of the KSTE in Innovation 
Given the availability of data and our research question, we created two distinctive data samples. We use a sample of 16,542 UK firms who reported innovative sales (\% of turnover) for all variables of interest $(21,702$ observations). Secondly, we use the sample of 16,542 UK firms reporting product innovation $(29,805$ obs.). Tables 1 and 2 illustrate the industrial, geographical, and time distribution of our sample across the originally matched sample UKIS-BSD and two samples of "innovative sales" of 21,702 observations and product innovation of 29,805 observations.

Most of the firms are from the South East of England (10.9\%), London (9.5\%), the North-West (9.2\%), and East England (8.9\%). Wales (<6\%), Scotland $(<9 \%)$ and Northern Ireland $(<8 \%)$. The industrial and geographical composition of firms does not change across multiple samples, which illustrates that the reduced samples are representative. The major differences were observed across survey waves 2002-2014. Most of the observations in our sample come from the first UKIS4 round (2002-2004)-57.8\% in the (innovative sales) sample, while its only $18.4 \%$ in the original sample. However, there is a symmetric distribution of firms in both samples and after the UK 2002-2004 wave. It is likely that the share of new product innovators

Table 1 Three samples sector divisions (by SIC 2007)

\begin{tabular}{|c|c|c|c|c|c|c|}
\hline Sector divisions & Baseline & $\%$ & $\begin{array}{l}\text { Innova- } \\
\text { tive sales } \\
\text { sample }\end{array}$ & $\%$ & $\begin{array}{l}\text { Product } \\
\text { innovator } \\
\text { sample }\end{array}$ & $\%$ \\
\hline 1 Mining \& Quarrying & 486 & 0.65 & 175 & 0.81 & 205 & 0.69 \\
\hline 2 Manufacturing basic & 4025 & 5.41 & 1277 & 5.88 & 1738 & 5.83 \\
\hline 3 High-tech manufacturing & 11,682 & 15.70 & 4218 & 19.44 & 5479 & 18.38 \\
\hline 4 Utility & 780 & 1.05 & 170 & 0.78 & 228 & 0.76 \\
\hline 5 Construction & 7370 & 9.90 & 2229 & 10.27 & 2925 & 9.81 \\
\hline 6 Wholesale, retail trade & 12,530 & 16.84 & 3481 & 16.04 & 4789 & 16.07 \\
\hline 7 Transport, storage & 4792 & 6.44 & 1195 & 5.51 & 1654 & 5.55 \\
\hline 8 Hotels \& restaurants & 5400 & 7.26 & 1174 & 5.41 & 1572 & 5.27 \\
\hline $9 \mathrm{ICT}$ & 4441 & 5.97 & 1434 & 6.61 & 1980 & 6.64 \\
\hline 10 Financial intermediation & 2651 & 3.56 & 850 & 3.92 & 1480 & 4.97 \\
\hline 11 Real estate \& other business activities & 10,728 & 14.41 & 2682 & 12.36 & 3844 & 12.90 \\
\hline 12 Public admin, defence & 8305 & 11.16 & 2196 & 10.12 & 3093 & 10.38 \\
\hline 13 Education & 213 & 0.29 & 152 & 0.70 & 212 & 0.71 \\
\hline 16 Other community, social activity & 1024 & 1.38 & 469 & 2.16 & 656 & 2.20 \\
\hline Total observations & $\mathbf{7 4 , 4 2 7}$ & 100.0 & 21,702 & 100.0 & 29,805 & 100.00 \\
\hline
\end{tabular}

Bold values indicate total number of observations used in each sample

Due to missing values on firm's sector the total amount of observations (once controlled for sectors $\backslash$ ) in the baseline sample is 74,427 obs

Source Office for National Statistics. (2017a). UK Innovation Survey, 1994-2016: Secure Access. [data collection]. 6th Edition. UK Data Service. SN: 6699, http://doi.org/10.5255/UKDA-SN-6699-6 (hereinafter UKIS- UK Innovation survey)

Office for National Statistics. (2017b). Business Structure Database, 1997-2017: Secure Access. [data collection]. 9th Edition. UK Data Service. SN: 6697, http://doi.org/10.5255/UKDA-SN-6697-9 (hereinafter BSD- Business Structure Database) 
Table 2 Three samples regional distribution (by 10 UK regions, Scotland and Northern Ireland) and distribution over survey waves

\begin{tabular}{|c|c|c|c|c|c|c|}
\hline Regions & Baseline & $\%$ & Innovative sales & $\%$ & $\begin{array}{l}\text { Product inno- } \\
\text { vator sample }\end{array}$ & $\%$ \\
\hline North East & 4731 & 5.28 & 1171 & 5.40 & 1752 & 5.88 \\
\hline North West & 8506 & 9.50 & 1997 & 9.20 & 2707 & 9.08 \\
\hline Yorkshire and Humber & 7142 & 7.98 & 1758 & 8.10 & 2455 & 8.24 \\
\hline East Midlands & 6708 & 7.49 & 1749 & 8.06 & 2364 & 7.93 \\
\hline West Midlands & 7562 & 8.45 & 1890 & 8.71 & 2549 & 8.55 \\
\hline Eastern England & 7776 & 8.69 & 1946 & 8.97 & 2708 & 9.09 \\
\hline London & 11,369 & 12.70 & 2064 & 9.51 & 2898 & 9.72 \\
\hline South East & 10,353 & 11.57 & 2367 & 10.91 & 3242 & 10.88 \\
\hline South West & 7229 & 8.08 & 1813 & 8.35 & 2510 & 8.42 \\
\hline Wales & 5203 & 5.81 & 1432 & 6.60 & 2000 & 6.71 \\
\hline Scotland & 7487 & 8.36 & 1700 & 7.83 & 2395 & 8.04 \\
\hline Northern Ireland & 5452 & 6.09 & 1815 & 8.36 & 2225 & 7.47 \\
\hline Total & 89,518 & 100.0 & 21,702 & 100.0 & 29,805 & 100.00 \\
\hline \multicolumn{7}{|l|}{ Years } \\
\hline UKIS4 (2005) & 16,445 & 18.37 & 12,557 & 57.86 & 12,554 & 42.12 \\
\hline UKIS5 (2007) & 14,872 & 16.61 & 2425 & 11.17 & 6264 & 21.02 \\
\hline UKIS6 (2009) & 14,281 & 15.95 & 1454 & 6.70 & 4734 & 15.88 \\
\hline UKIS7 (2011) & 14,342 & 16.02 & 2773 & 12.78 & 2853 & 9.57 \\
\hline UKIS8 (2013) & 14,487 & 16.18 & 1174 & 5.41 & 1509 & 5.06 \\
\hline UKIS9 (2015) & 15,091 & 16.86 & 1319 & 6.08 & 1891 & 6.34 \\
\hline Total observations & 89,518 & 100.0 & 21,702 & 100.0 & 29,805 & 100.00 \\
\hline
\end{tabular}

Bold values indicate total number of observations used in each sample

Source UKIS UK innovation survey, $B S D$ business structure database

as well as the number of firms who responded to a survey dropped significantly in the post-crises period.

\subsection{Variables}

Table 3 provides the list of variables, their sources, and description, while the summary statistics is presented in Table 4.

Beneath Table 4 we explained how spillover components (0- not applicable to 3 high) were measured and calculated. Table 4 also illustrates summary statistics.

Our first dependent variable (DV) is the share of new to market products $[0-, 100]$. Based on the availability for this variable, we created a sample of 21,702 obs. Our second DV Second is a dichotomous variable that takes value 1 when the firm declares it has introduced something completely new to the market, zero otherwise (Santamaria et al. 2009; Baker et al. 2016; Audretsch and Belitski 2019). Based on the availability for this variable, we created a sample of 29,805 obs.

Explanatory variables. 
Table 3 Description of variables

\begin{tabular}{ll}
\hline Variable (source) & Definition \\
\hline Innovative sales (UKIS) & $\begin{array}{c}\text { Dependent variable: \% of firm's total turnover from goods and ser- } \\
\text { vices that were new to the market (\%) } \\
\text { Dependent variable: Binary variable }=1 \text { if firm reports positive firm's } \\
\text { turnover from goods and services that were new to the market or } \\
\text { new to the firm, zero otherwise }\end{array}$
\end{tabular}

Independent variables

Knowledge spillovers (UKIS)

Sum of scores ( 0 to 3 ) of how important to innovation activities was information from: conferences, trade fairs or exhibitions; professional and industry associations; technical, industry or service standards; scientific journals and trade/technical publication (rescaled between zero and one). The individual variables are described below

Associations (UKIS)

Knowledge spillovers component: how important to innovation activities was information from: professional and industry associations (0 not applicable to 3 high)

Standards (UKIS)

Conferences (UKIS)

Publications (UKIS)

Collaboration regional

(UKIS)

Collaboration national (UKIS)

Collaboration international (UKIS)

Start-ups

Knowledge spillovers component: how important to innovation activities was information from: technical, industry or service standards (0 not applicable to 3 high)

Knowledge spillovers component: how important to innovation activities was information from: conferences, trade fairs or exhibitions ( 0 not applicable to 3 high)

Knowledge spillovers component: how important to innovation activities was information from: scientific journals and trade/technical publications (0 not applicable to 3 high)

Binary variable $=1$ if firm collaborates on innovation regionally with at least one partner: enterprise group, suppliers; customers; competitors; consultants, commercial labs; universities; government and public research institutes, zero otherwise

Binary variable $=1$ if firm collaborates on innovation nationally with at least one partner: enterprise group, suppliers; customers; competitors; consultants, commercial labs; universities; government and public research institutes, zero otherwise

Binary variable $=1$ if firm collaborates on innovation in Europe and other world with at least one partner: enterprise group, suppliers; customers; competitors; consultants, commercial labs; universities; government and public research institutes, zero otherwise

Binary variable equal one if a firm is from $0-3$ years old since establishment has maximum (50 employees at establishment) and is not part of an enterprise group, including no units at establishment, zero otherwise

Control variables

Age (BSD)

Employment (BSD)

Age of a firm (years since the establishment)

High-tech manufacturing (UKIS)

Number of full time employees, in logarithms

Binary variable equal one if SIC2007 (2 digit): 21, 26, 30, zero otherwise

Med-tech manufacturing (UKIS) Binary variable equal one if SIC2007 (2 digit): 20, 22-25, 27-29, 32, zero otherwise

Risk (UKIS)

Binary variable $=1$ if firm has experienced constraining innovation activities such as excessive perceived economic risks, zero otherwise

Cost (UKIS)

Binary variable $=1$ if firm has experienced constraining innovation activities such as cost of finance, zero otherwise 
Table 3 (continued)

\begin{tabular}{|c|c|}
\hline Variable (source) & Definition \\
\hline Technology constraint (UKIS) & $\begin{array}{l}\text { Binary variable }=1 \text { if firm has experienced constraining innovation } \\
\text { activities such as lack of information on technology, zero otherwise }\end{array}$ \\
\hline Scientist (UKIS) & $\begin{array}{l}\text { The proportion of employees that hold a degree or higher qualification } \\
\text { in science and engineering at } \mathrm{BA} / \mathrm{BSc}, \mathrm{MA} / \mathrm{PhD} \text {, PGCE levels }\end{array}$ \\
\hline Exporter (UKIS) & $\begin{array}{l}\text { Binary variable }=1 \text { if a firm sells its products in foreign markets, } 0 \\
\text { otherwise }\end{array}$ \\
\hline Survival 2017 year $(B S D)$ & $\begin{array}{l}\text { Binary variable }=1 \text { if a firm survived as an independent unit or as a } \\
\text { part of a group until year } 2017,0 \text { otherwise }\end{array}$ \\
\hline HHI (BSD) & $\begin{array}{l}\text { The Herfindahl-Hirschman Index, HHI, is a measure of the size of } \\
\text { firms in relation to the industry by employment at two-digit SIC } \\
2007(0-1)\end{array}$ \\
\hline Foreign & Binary variable $=1$ if a firm has headquarters abroad, 0 otherwise \\
\hline Reporting units & $\begin{array}{l}\text { Number of local units (subsidiaries within the enterprise group, both } \\
\text { in the country and abroad) }\end{array}$ \\
\hline R\&D intensity (UKIS) & $\begin{array}{l}\text { The amount of expenditure for internal Research and Development } \\
(000 \mathrm{~s}) \text {, to total sales }(000 \mathrm{~s} \text { pound sterling })\end{array}$ \\
\hline Appropriability (UKIS) & $\begin{array}{l}\text { How effective were various legal and strategic methods for maintain- } \\
\text { ing or increasing the competitiveness of product and process innova- } \\
\text { tions rescaled from zero to one using the data on: patents, copyright, } \\
\text { trademarks, secrecy, first entry }(0-\text { not applicable to } 3-\text { high }) \text { ? }\end{array}$ \\
\hline Software (UKIS) & $\begin{array}{l}\text { The amount of expenditure for purchasing advanced machinery, equip- } \\
\text { ment and software }(000 \mathrm{~s}) \text { to total sales }(000 \mathrm{~s} \text { pound sterling) }\end{array}$ \\
\hline
\end{tabular}

Source UKIS UK innovation survey, BSD business structure database

Our explanatory variable is a knowledge spillover, which is measured differently from Keller (2002), Bloom et al. (2013), (Giovannetti and Piga 2017). They are not biased by the geographical distance of knowledge creation and commercialization (Audretsch and Feldman 1996), investment in R\&D, or researcher employment in an industry or within certain geographical proximity. The size of the knowledge spillover is measured by the importance of information (from zero-not important to 3-very important) from external open sources (Cassiman and Veugelers 2002; West and Bogers 2014) such as conferences, trade fairs or exhibitions; professional and industry associations; technical, industry or service standards; scientific journals and trade/technical publication (rescaled between zero and one). Whether these knowledge sources necessarily constitute spillovers in a strict sense is an issue for debate, but they do make up important external knowledge inputs, not necessarily involving an interactive relationship between the knowledge creator and the knowledge users.

We include binary variable equal one if firm is an innovative start-up, zero otherwise. We define an 'innovative start-up' as a firm that is a maximum of 7 years old, has no subsidiaries and is itself a firm and not a subsidiary (Zahra 1996). The maximum number of employees is limited to 10-49 in the year of incorporation. We assume a start-up is innovative if it performs at least two out of three activities. Firstly, if it invests in its own R\&D, and/or external R\&D. Secondly, if the firm innovates new products and processes and commercializes it in domestic and foreign markets.

Control variables. 
Table 4 Summary statistics for variables used in this study across four samples

\begin{tabular}{|c|c|c|c|c|c|c|c|}
\hline \multirow{2}{*}{$\begin{array}{l}\text { Sample } \\
\text { Variables }\end{array}$} & \multicolumn{3}{|c|}{ Initial match UKIS and BSD } & \multicolumn{2}{|c|}{$\begin{array}{l}\text { Innovative } \\
\text { sales }=21,702 \text { obs }\end{array}$} & \multicolumn{2}{|c|}{$\begin{array}{l}\text { Product innovator } \\
\text { sample }=29,805 \\
\text { obs }\end{array}$} \\
\hline & Obs & Mean & SD & Mean & SD & Mean & SD \\
\hline Innovative sales & 33,969 & 4.68 & 13.67 & 4.24 & 12.79 & & \\
\hline Product innovator & 89,518 & 0.24 & 0.43 & 0.41 & 0.49 & 0.36 & 0.48 \\
\hline Knowledge spillover & 89,518 & 0.19 & 0.27 & 0.29 & 0.27 & 0.29 & 0.28 \\
\hline Collaboration regional & 73,435 & 0.13 & 0.34 & 0.14 & 0.35 & 0.15 & 0.35 \\
\hline Collaboration national & 73,431 & 0.18 & 0.39 & 0.18 & 0.39 & 0.19 & 0.40 \\
\hline Collaboration international & 89,518 & 0.09 & 0.29 & 0.12 & 0.32 & 0.12 & 0.32 \\
\hline Start-ups & 64,192 & 0.09 & 0.28 & 0.07 & 0.25 & 0.07 & 0.26 \\
\hline Age & 64,192 & 18.32 & 10.80 & 17.93 & 9.78 & 18.25 & 9.76 \\
\hline Employment & 89,505 & 4.09 & 1.52 & 4.02 & 1.49 & 4.07 & 1.51 \\
\hline High-tech manufacturing & 89,518 & 0.01 & 0.09 & 0.01 & 0.06 & 0.01 & 0.07 \\
\hline Med-tech manufacturing & 89,518 & 0.07 & 0.25 & 0.06 & 0.23 & 0.06 & 0.25 \\
\hline Risk & 67,951 & 1.16 & 1.18 & 1.18 & 1.13 & 1.15 & 1.14 \\
\hline Cost & 68,162 & 1.13 & 1.14 & 1.10 & 1.09 & 1.08 & 1.10 \\
\hline Technology constraint & 67,753 & 0.80 & 0.88 & 0.76 & 0.83 & 0.75 & 0.83 \\
\hline Scientist & 66,559 & 6.79 & 16.26 & 7.20 & 17.02 & 7.18 & 17.00 \\
\hline Exporter & 89,518 & 0.31 & 0.46 & 0.38 & 0.48 & 0.37 & 0.48 \\
\hline Survival 2017 year & 89,518 & 0.49 & 0.50 & 0.57 & 0.49 & 0.59 & 0.49 \\
\hline HHI & 89,518 & 0.05 & 0.07 & 0.04 & 0.05 & 0.04 & 0.06 \\
\hline Foreign & 64,211 & 0.31 & 0.46 & 0.45 & 0.49 & 0.43 & 0.49 \\
\hline Reporting units & 64,192 & 1.33 & 2.44 & 1.42 & 2.51 & 1.44 & 2.61 \\
\hline R\&D intensity & 45,321 & 0.01 & 0.06 & 0.01 & 0.05 & 0.01 & 0.05 \\
\hline Appropriability & 89,518 & 0.29 & 0.76 & 0.43 & 0.91 & 0.40 & 0.96 \\
\hline Software & 47,476 & 0.01 & 0.05 & 0.01 & 0.04 & 0.01 & 0.04 \\
\hline Associations & 89,518 & 0.61 & 0.93 & 0.92 & 0.96 & 0.89 & 0.97 \\
\hline Standards & 89,518 & 0.65 & 0.98 & 0.96 & 1.03 & 0.95 & 1.03 \\
\hline Conferences & 89,518 & 0.58 & 0.91 & 0.89 & 0.97 & 0.86 & 0.97 \\
\hline Publications & 89,518 & 0.50 & 0.82 & 0.80 & 0.90 & 0.77 & 0.90 \\
\hline
\end{tabular}

Source UKIS UK innovation survey, BSD business structure database

Each equation has a specific set of additional control variables. The set of variables describing knowledge collaboration in regional, national and global markets reported by the firms in the CIS surveys (Leiponen and Helfat 2010; Roper et al. 2017). Variety of knowledge collaborations is in the essence of two types of knowledge inputs-spillovers and knowledge collaboration that are complements. For instance, a firm could learn to use one type of external input (codified knowledge sources), and this learning could facilitate the successful use of the other external knowledge input (collaboration for innovation).

We also included controls for R\&D intensity, appropriability, firm age, firm size, innovation constraints, organizational innovation. We use the following fixed-effects controls: year of the innovation survey (2002-2004 as a reference year), 128 city-regions (York city as a reference category), 2-digit industry controls (mining and agriculture 
as reference category). For the full list of variables used to predict innovation performance, please see Table 3 .

\subsection{Method}

We estimated the following model with a dependent variable $y_{i}$ (firm's innovation) as a continuous (innovation sales) and binary variable (propensity to innovate) as a function of a set of explanatory and control variables:

$$
y_{i t}=\beta_{0}+\beta_{i} S_{i t}+\omega_{i} \varphi_{i t}+k_{i} x_{i t}+\psi_{i} \varphi_{i t} S_{i t}+u_{i t}
$$

We can also call it structural equation to emphasize that we were interested in $\beta_{i}$ and that the equation to be measured as causal. Variable $\varphi_{i t}$ is firm's innovation, including knowledge spillovers, $S_{i t}$ is a binary variable, which identifies innovative start-up and $u_{i t}$ is an error term. $x_{i t}$ is a list of exogenous control variables and not correlated with $u_{i t}$, Our knowledge spillover variable is also exogenous $\varphi_{i t}$ and is unlikely to be correlated with $u_{i t}$ (Wooldridge 2009: 517). $\varphi_{i t} S_{i t}$ is an interaction term which demonstrate the difference in the size of the relationship between knowledge spillover and innovation performance for start-ups as oppose to incumbents.

We estimate Eq. (1) using a multivariate Tobit model for DV1 and probit model doe DV2. As additional covariates this stage includes a set of control variables, the knowledge spillovers and the interaction between the knowledge spillover and innovative start-up identifier.

\section{Results}

The hypotheses testing results are presented in Tables 5 and 6, which also includes a series of robustness checks. First, we estimated an innovation production function using the random-effects Tobit model (spec.1-5, Table 5) of 21,702 observations. We calculated a likelihood-ratio test comparing the panel Tobit model with the pooled Tobit model (see beneath Table 5) with the test supporting the use of panel estimation.

The coefficients in Table 5 present the marginal effect of the independent variables on the innovation performance (\% sales of new-to-market products) and innovation propensity. Robust standard errors are estimated for these coefficients. Regression (1) includes only control variables, while regression (2) adds knowledge spillover and regression and (3) ass additional controls for three geographical dimensions of knowledge collaboration with external partners (Van Beers and Zand 2014). The overall predictive power of the estimated innovation functions (2) and (3) in Table 5 is higher than in regression (1) as we control for knowledge inputs related to innovation. An increase in one standard deviation of knowledge spillover increases the share of new to market product sales by $20.56 \%$ $(\beta=20.56, p<0.001)$. The coefficient values drop to $15.19 \%(\beta=15.19, p<0.001)$ when controlling for regional and national external knowledge collaboration, which complements knowledge spillover. Once we control for investment in internal knowledge (Cohen and Levinthal 1989; Denicolai et al. 2016; Roper et al. 2017), the value of the knowledge spillover coefficient drops to $10.69 \%(\beta=10.69, p<0.001)$. Our results support prior research on the effect of knowledge spillovers on innovation. 
Table 5 Results of Tobit estimation (all firms). Dependent variable: Innovation is taken in \% and varies from $(0-100 \%)$

\begin{tabular}{|c|c|c|c|c|c|}
\hline \multirow[t]{2}{*}{ Variables } & (1) & (2) & (3) & (4) & (5) \\
\hline & Tobit & Tobit & Tobit & Tobit & Tobit \\
\hline Knowledge spillover $\beta_{1}$ & & $\begin{array}{l}20.56^{* * *} \\
(1.81)\end{array}$ & $\begin{array}{l}15.19 * * * \\
(1.58)\end{array}$ & $\begin{array}{l}10.69 * * * \\
(1.53)\end{array}$ & $\begin{array}{l}9.58 * * * \\
(1.53)\end{array}$ \\
\hline Collaboration regional & & & $\begin{array}{l}4.11 * * * \\
(.67)\end{array}$ & $\begin{array}{l}4.71 * * * \\
(.74)\end{array}$ & $\begin{array}{l}4.80 * * * \\
(.71)\end{array}$ \\
\hline Collaboration national & & & $\begin{array}{l}7.09 \text { *** } \\
(.85)\end{array}$ & $\begin{array}{l}8.49 * * * \\
(.87)\end{array}$ & $\begin{array}{l}8.50 * * * \\
(.85)\end{array}$ \\
\hline Collaboration international & & & $\begin{array}{l}4.34 * * * \\
(1.21)\end{array}$ & $\begin{array}{l}2.37 * \\
(1.12)\end{array}$ & $\begin{array}{l}1.73^{*} \\
(0.65)\end{array}$ \\
\hline$R \& D$ intensity & & & & $\begin{array}{l}63.22 * * * \\
(7.91)\end{array}$ & $\begin{array}{l}62.31 \text { *** } \\
(7.71)\end{array}$ \\
\hline Appropriability & & & & $\begin{array}{l}33.08 * * * \\
(3.5)\end{array}$ & $\begin{array}{l}33.17 * * * \\
(3.5)\end{array}$ \\
\hline Software & & & & $\begin{array}{l}34.49 * * * \\
(6.2)\end{array}$ & $\begin{array}{l}34.60 * * * \\
(6.2)\end{array}$ \\
\hline Knowledge spillover x startups $\beta_{2}(\mathrm{H} 1)$ & & & & & $\begin{array}{l}9.76^{* * *} \\
(5.1)\end{array}$ \\
\hline Start-ups $\beta_{2}$ & $\begin{array}{l}3.41 * \\
(1.5)\end{array}$ & $\begin{array}{l}3.60 * \\
(1.4)\end{array}$ & $\begin{array}{l}3.75^{*} \\
(1.6)\end{array}$ & $\begin{array}{l}3.21^{*} \\
(1.5)\end{array}$ & $\begin{array}{l}-1.80 \\
(2.3)\end{array}$ \\
\hline Age & $\begin{array}{l}-0.48 * * * \\
(.08)\end{array}$ & $\begin{array}{l}-0.47 * * * \\
(.08)\end{array}$ & $\begin{array}{l}-0.42 * * * \\
(.08)\end{array}$ & $\begin{array}{l}-0.36^{* * *} \\
(.04)\end{array}$ & $\begin{array}{l}-0.37 * * * \\
(.04)\end{array}$ \\
\hline Age squared & $\begin{array}{l}0.01 * * \\
(.00)\end{array}$ & $\begin{array}{l}0.01 * * \\
(.00)\end{array}$ & $\begin{array}{l}0.01 * * \\
(.00)\end{array}$ & $\begin{array}{l}0.01 * * \\
(.00)\end{array}$ & $\begin{array}{l}0.01 * * \\
(.00)\end{array}$ \\
\hline Employment & $\begin{array}{l}-0.21 \\
(.28)\end{array}$ & $\begin{array}{l}-0.72 * \\
(.28)\end{array}$ & $\begin{array}{l}-1.07 * * * \\
(.28)\end{array}$ & $\begin{array}{l}-1.22 * * * \\
(.29)\end{array}$ & $\begin{array}{l}-1.18^{* * * *} \\
(.28)\end{array}$ \\
\hline High-tech manufacturing & $\begin{array}{l}5.73 \\
(3.90)\end{array}$ & $\begin{array}{l}5.54 \\
(4.20)\end{array}$ & $\begin{array}{l}4.73 \\
(4.10)\end{array}$ & $\begin{array}{l}3.19 \\
(4.20)\end{array}$ & $\begin{array}{l}2.92 \\
(4.10)\end{array}$ \\
\hline Med-tech manufacturing & $\begin{array}{l}-0.04 \\
(2.10)\end{array}$ & $\begin{array}{l}0.81 \\
(1.90)\end{array}$ & $\begin{array}{l}1.11 \\
(2.01)\end{array}$ & $\begin{array}{l}1.32 \\
(1.50)\end{array}$ & $\begin{array}{l}1.33 \\
(1.53)\end{array}$ \\
\hline Risk & $\begin{array}{l}2.98 * * * \\
(.37)\end{array}$ & $\begin{array}{l}2.29 * * * \\
(.35)\end{array}$ & $\begin{array}{l}1.95 * * * \\
(.35)\end{array}$ & $\begin{array}{l}1.90 * * * \\
(.41)\end{array}$ & $\begin{array}{l}1.92^{* * * *} \\
(.41)\end{array}$ \\
\hline Cost & $\begin{array}{l}1.76 * * * \\
(.37)\end{array}$ & $\begin{array}{l}1.26 * * * \\
(.35)\end{array}$ & $\begin{array}{l}1.40 * * * \\
(.35)\end{array}$ & $\begin{array}{l}0.94 * * \\
(.33)\end{array}$ & $\begin{array}{l}0.95 * * \\
(.33)\end{array}$ \\
\hline Technology constraint & $\begin{array}{l}2.33 * * * \\
(.31)\end{array}$ & $\begin{array}{l}1.17 * * \\
(.36)\end{array}$ & $\begin{array}{l}1.18 * * * \\
(.35)\end{array}$ & $\begin{array}{l}0.67 \\
(.37)\end{array}$ & $\begin{array}{l}0.64 \\
(.38)\end{array}$ \\
\hline Scientist & $\begin{array}{l}0.27 * * * \\
(.03)\end{array}$ & $\begin{array}{l}0.23 * * * \\
(.03)\end{array}$ & $\begin{array}{l}0.20 * * * \\
(.02)\end{array}$ & $\begin{array}{l}0.12 * * * \\
(.01)\end{array}$ & $\begin{array}{l}0.12 * * * \\
(.01)\end{array}$ \\
\hline Exporter & $\begin{array}{l}10.45^{* * * *} \\
(.88)\end{array}$ & $\begin{array}{l}9.24 * * * \\
(.82)\end{array}$ & $\begin{array}{l}7.83 * * * \\
(.84)\end{array}$ & $\begin{array}{l}6.26 * * * \\
(.78)\end{array}$ & $\begin{array}{l}6.09 * * * \\
(.78)\end{array}$ \\
\hline Survival 2017 year & $\begin{array}{l}0.29 \\
(.47)\end{array}$ & $\begin{array}{l}0.21 \\
(.49)\end{array}$ & $\begin{array}{l}0.09 \\
(.47)\end{array}$ & $\begin{array}{l}0.50 \\
(.48)\end{array}$ & $\begin{array}{l}0.50 \\
(.48)\end{array}$ \\
\hline Foreign & $\begin{array}{l}-0.56 \\
(0.80)\end{array}$ & $\begin{array}{l}-1.01 \\
(0.82)\end{array}$ & $\begin{array}{l}-1.26 \\
(0.74)\end{array}$ & $\begin{array}{l}-2.01 * * \\
(0.65)\end{array}$ & $\begin{array}{l}-1.97 * * \\
(0.70)\end{array}$ \\
\hline Reporting units & $\begin{array}{l}0.04 \\
(.08)\end{array}$ & $\begin{array}{l}0.04 \\
(.07)\end{array}$ & $\begin{array}{l}0.01 \\
(.07)\end{array}$ & $\begin{array}{l}-0.04 \\
(.06)\end{array}$ & $\begin{array}{l}-0.03 \\
(.06)\end{array}$ \\
\hline Constant & $\begin{array}{l}-36.01 * * \\
(3.90)\end{array}$ & $\begin{array}{l}-38.88^{* *} \\
(3.90)\end{array}$ & $\begin{array}{l}-36.96^{* *} \\
(3.80)\end{array}$ & $\begin{array}{l}-34.19^{* *} \\
(4.20)\end{array}$ & $\begin{array}{l}-40.28^{* * *} \\
(4.10)\end{array}$ \\
\hline Number of obs & 21,702 & 21,702 & 21,702 & 21,702 & 21,702 \\
\hline Left censored & 16,430 & 16,430 & 16,430 & 16,430 & 16,430 \\
\hline
\end{tabular}


Table 5 (continued)

\begin{tabular}{llllll}
\hline Variables & $(1)$ & $(2)$ & $(3)$ & $(4)$ & $(5)$ \\
& Tobit & Tobit & Tobit & Tobit & Tobit \\
\hline $\begin{array}{l}\text { Dropped from the sample } \\
\text { Log-likelihood }\end{array}$ & & & & & \\
Chi2 & $-33,519.91$ & $-33,343.47$ & $-33,115.91$ & $-29,313.05$ & $-29,292.68$ \\
LR test of sigma $\mathrm{u}=0:$ & .091 & .097 & .101 & .112 & .119 \\
\hline
\end{tabular}

Reference category for legal status is Company (limited liability company), industry (mining), region (North East of England). Instead of industry dummies in this estimation employment (in logs is used)

Robust standard errors are in parenthesis. The coefficients of the tobit and probit regressions are the marginal effect of the independent variable on the probability of Knowledge spillover, knowledge collaboration, ceteris paribus. For dummy variables, it is the effect of a discrete change from 0 to 1

Significance level: $* p<0.05 ; * * p<0.01, * * * p<0.001$

Our hypotheses that start-ups have greater returns to knowledge spillovers for innovation is supported. We test this by interacting the binary variable "start-ups" with a knowledge spillover (Table 5, spec. 5). The interaction coefficients in spec. 5 (Table 5) is 9.76 $(\beta=9.76, p<0.05)$, which means that an increase in knowledge spillover by one standard deviation adds $19.34 \%(\beta=9.76+9.58, p<0.05)$ to new product sales for start-ups, while for incumbent firms, the size of the effect is $9.58 \%$.

The signs and significance levels of all the coefficients-determinants of innovation in Table 5-remain robust across different regressions. The coefficients of collaboration with regional, national, and international partners also drop once controlling for other inputs. Collaboration with at least one regional partner increases innovation performance by $4.7 \%$ $(\beta=4.71, p<0.001)$, or $8.5 \%$ when collaborating nationally $(\beta=8.49, p<0.001)$ and $2.4 \%$ when collaborating internationally $(\beta=2.37, p<0.05)$ (Table 5, spec. 4$)$.

The positive coefficient of appropriability demonstrates that firms that legally and strategically protect their innovations (Arora et al. 2016) also achieve on average $33.08 \%$ higher innovation sales $(\beta=33.08, p<0.001)$ than firms that do not appropriate their knowledge. The effect of $R \& D$ intensity $(\beta=63.22, p<0.001)$ and software intensity $(\beta=34.49$, $p<0.001)$ is positive and significant.

Start-ups have positive effects on innovation output $(\beta=3.21, p<0.05)$ (spec. 4$)$, which means that start-ups innovate on average between 3.20 and $3.75 \%$ more than incumbents. The effect of firm age is U-shaped and significant across all specifications in Table 5.

Cost- and risk-sharing are important drivers of innovation. Firms that perceive risk and cost as key barriers to innovation are more likely to have higher innovation outputs. Viewed from the innovation perspective, this result is not so surprising. Producing innovation is associated with higher uncertainty, cost, and risk, which firms experience when engaging in new product commercialization. The effect of lack of information on technology disappears once we controlled for knowledge inputs ( $R \& D$ and software investment intensity) and appropriability. The result is intriguing, as it indicates that a lack of technology could be leveraged by an increase in absorptive capacity and knowledge collaboration.

A higher share of employees with postgraduate degrees as a proxy for human capital increases innovation output $(\beta=0.12-0.23, p<0.001)$. Exports have on average $6-10 \%$ higher innovation sales when controlling for all explanatory and other variables $(\beta=6.26$, $p<0.001$ ) (Table 5, spec. 4). A binary variable "survival" picks up firms that survived 


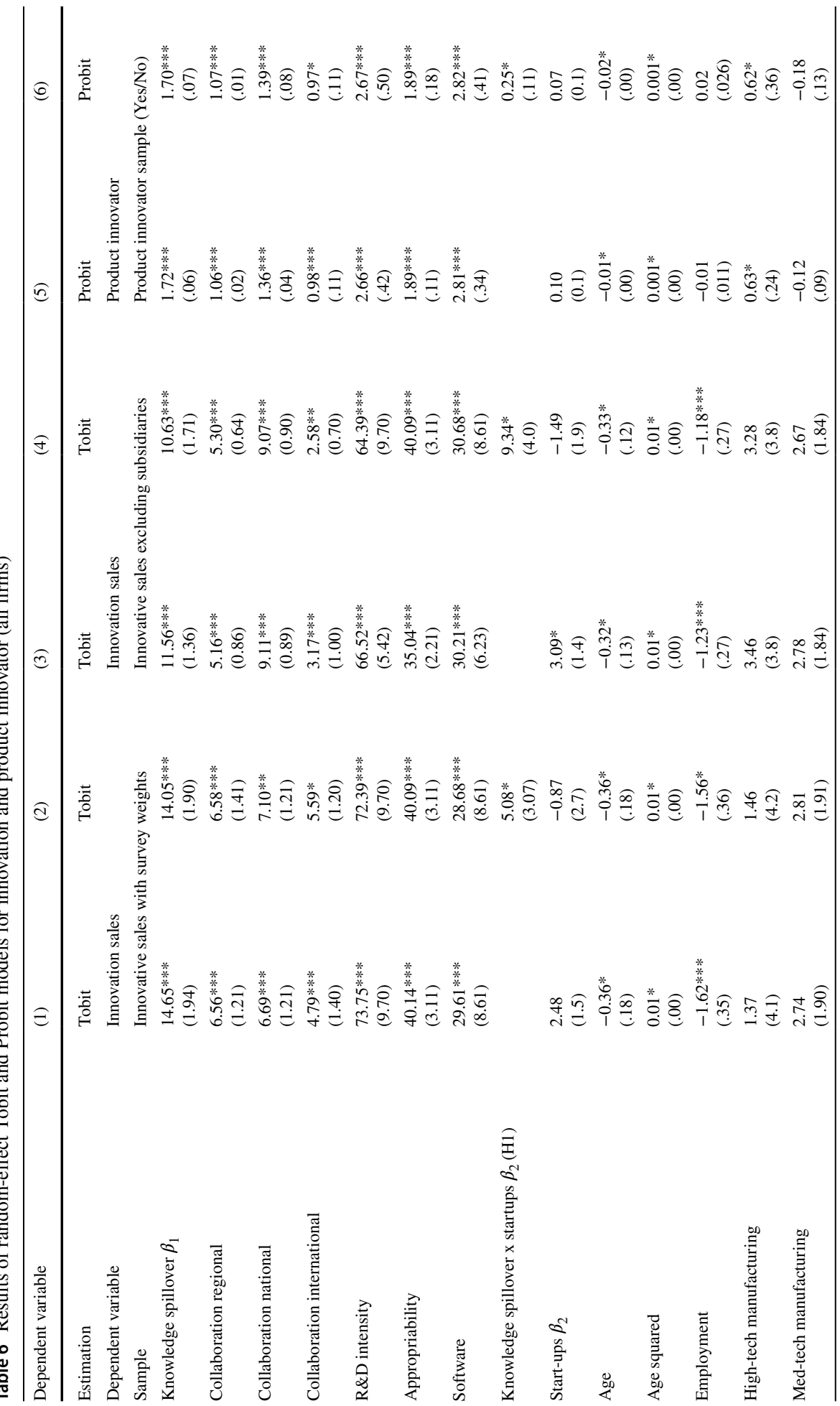

\section{Springer}




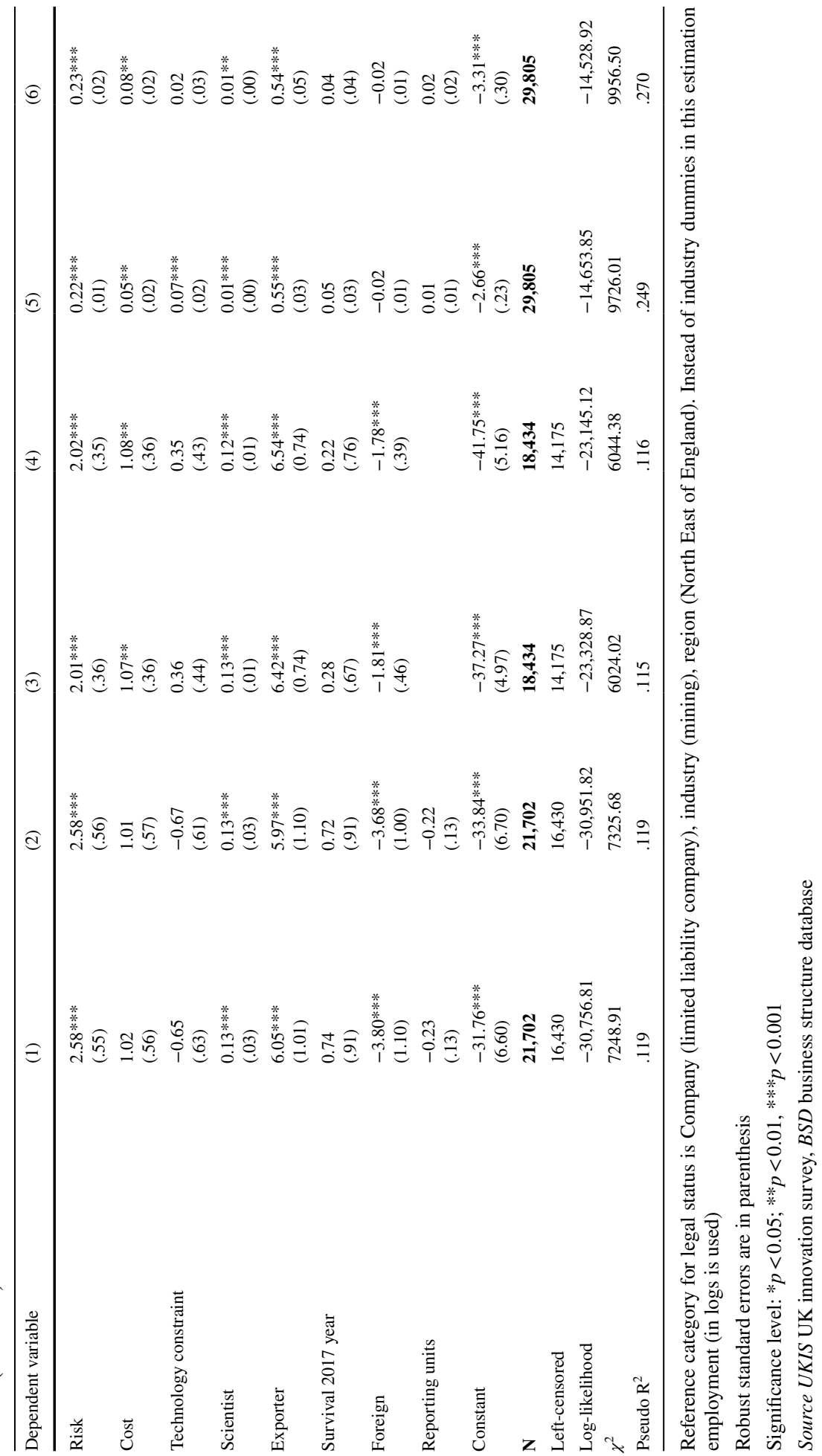


from 2000 until 2017 is positive but insignificant. This result demonstrates that innovation is not a guarantee for survival, and firms who survive may not be leading innovators or followers. There are no differences in innovation sales between high- and medium-tech manufacturing firms and non-manufacturing firms.

Post-hoc analysis.

First, we started our analysis by controlling for potential sample selection bias. In our sample, the dependent variable can only be measured when the firm innovates. Out of 89,518 observations collected in the original sample by the UKIS during 2002-2014, only 49.0 percent of observations are available for product innovation created in-house, 47.7 percent of observations - for innovation with other businesses and 37.9 percent of new to market product sales. Each round of UKIS is collected as a stratified sample (Office of National Statistics 2017a), a pull of firms by industry, region, and size.

Given our sample is stratified by industry, UK region, and firm size, we applied survey weights and used Tobit estimation (spec. 1-2 in Table 6) with UKIS survey probability weights for each firm in the sample. Weighting is not applied in other models, and the original numbers (not inflated due to weighting) were reported. Our coefficient of interest - the interaction between innovative-start-ups and knowledge spillover is positive and statistically significant $(\beta=5.08, p<0.05)$, supporting KSTE for the global sample and again evidences no sample selection bias.

As the next step of the robustness check, we excluded all firms with at least one subsidiary since other subsidiaries could benefit from the knowledge spillover. We excluded all firms that reported having at least one subsidiary (spec. 3-4 in Table 6), resulting in a sample reduction to 18,434 observations. Our coefficient of interest is positive and statistically significant $(\beta=9.34, p<0.05)$, supporting KSTE for firms without subsidiaries, which would also exclude multinational firms. Finally, we estimated the probit model in Table 6 (spec. 5-6) as part of a robustness check with a binary dependent variable "product innovation" (29,805 observations).

The interaction coefficient is positive and statistically significant $(\beta=0.25, p<0.05)$, which means that start-ups are the more efficient conduit of knowledge spillover to innovation than the incumbent firm supporting our hypotheses. The use of two variations of innovation performance is important for the robustness of our finding. Our dependent variable-a share of new to market product sales (0-100) reflects the share of a firm's turnover from goods and services that were new to the market. There certainly needs to be more consistency in scholars' approach and theorize innovation performance. Our central finding is that start-ups are more likely to benefit from knowledge spillovers than incumbent firms.

\title{
5 Discussion and Conclusion
}

\author{
Policy Implications.
}

As with many studies that focus on relatively new mechanisms of public policy to support entrepreneurship such as knowledge spillovers, this paper points out using the case of the innovative UK firms that external knowledge-based mechanisms can be used as a complementary and robust source of knowledge for innovative firms and in particular for start-ups. This has a direct implication for public policy. First, factors that facilitate 
entrepreneurial activity in cities and countries (Audretsch et al. 2015) are directly linked to economic growth in developed and developing countries (van Stel et al. 2005). This is except unproductive and destructive entrepreneurial activity, which hurts economic growth in developing countries (Acs and Varga 2005) and in countries with a weak institutional framework (Baumol 1993; Chowdhury et al. 2019), which is not part of this study. Second, Information from external sources is likely to be complementary to internal investment in knowledge and collaboration with external partners on innovation, and a range of such sources has not been taken into account in the knowledge transfer literature.

Taking knowledge spillovers generated by external sources into account in setting national policies to support entrepreneurial activity is important, and policymakers constantly confront a series of decisions about new avenues to spur innovation and entrepreneurialism. Many factors affect how fiscal and other forms of support are made (Acs and Szerb 2007), given the strong association between long-term economic development and entrepreneurship. There are several essential implications for policy to consider related to our findings.

A strong collaboration with external partners, including suppliers, customers, competitors, consultants (Belitski 2019) as well as university and research laboratories (Link and Scott 2019; Audretsch and Link 2019b) enhances absorptive capacity (Spithoven et al. 2010) easing the recognition and use of external information sources, including the development of strategic, operational and digital skills and competences in SMEs (Khalil and Belitski 2020). Provided the right incentives to reward external collaboration with different partners, the greater the proportion of information available at conferences, patents, journals, and other sources is more likely to be recognized, transferred to a firm, and further commercialized. Innovation in start-ups requires skills and competencies which may not be available in-house, and external information spillovers can be refined, marketed, and adopted by entrepreneurs to leverage innovation inputs. America owes much of its success in knowledge transfer to its enviable record in providing excellent access to data on patents, licenses at the agency level through the Technology Partnerships Office (TPO) at the National Institute of Standards and Technology (NIST), the Board on Science and Technology Policy (STEP) at the National Academies (the National Academy of Sciences, the National Academy of Engineering, and the Institute of Medicine while federal laboratories have historically been reluctant to make public their data on technology transfer activities (Link et al. 2019). Knowledge transfer between research labs and entrepreneurs have also been declared by President Obama's 2011 Memorandum (Link and Oliver 2020). These memorandums and collaborations are limited to supply start-up innovators with relevant information from national research agencies and laboratories. Start-ups continue to rely on publicly available information as innovation inputs.

Improvements in innovation come through technical change, which requires both the investment in internal knowledge and the discovery of new ideas and information from external sources, made available publicly or privately. New information, in turn, are the product of research and development of other firms and universities (Audretsch and Link 2019a, b; Audretsch and Belitski 2019), which span the range from basic research (such as the discovery of new scientific laws) (Audretsch 2014) or to development of innovation activities and achieving higher productivity (the embodiment of new ideas in products, or innovation techniques (Audretsch and Belitski 2020b). It is now well understood that because the benefits of basic research at universities and federal laboratories cannot be 
fully captured by those who pursue it (Chen et al. 2018; Link and Oliver 2020), start-ups will be better off if the government funds activities and collaboration projects and either pursue it directly or contracts it to universities and research organizations who have this information available and who require start-up skills and market knowledge to commercialize it.

Theoretical implications.

Endogenous growth theories assume market failures on at least one aspect of innovation. Complete appropriability yields the right incentives but hinders economic growth, whereas availability of knowledge spillovers spurs diffusion of new ideas, which creates market opportunities for start-ups (Audretsch and Keilbach 2007; Acs et al. 2009; Audretsch and Link 2019c) but destroys incentives for larger firms to invest in knowledge. Our finding concludes that start-ups are direct beneficiaries of knowledge spillovers and that the KSTE better explains the mechanisms of knowledge transfer in younger firms. While imperfect appropriability of knowledge creates market opportunities for large firms, knowledge spillover facilitates knowledge transfer to firms that lack internal knowledge and rely on external innovation inputs. Consequently, the efficiency of information obtained by attending a conference, via formal and informal networks and associations, and accessing open publications and patents enables to leverage the lack of investment in internal knowledge by start-ups and bring a new diverse source of ideas to be commercialized.

Managerial Implications.

This research should help managers make two important decisions about knowledge spillover: what are the origins of knowledge and their efficiency (e.g., conferences, fairs, technical and professional associations, patents and publications), at what stage of firm growth access to knowledge spillover becomes more critical. Firms may reduce their investment in R\&D when knowledge spillovers are high, and the appropriability of knowledge cannot be directly enforced. Our research findings indicate that start-ups that perceive external information to be more important as knowledge spillover can transfer this knowledge into innovation performance most efficiently than incumbent firms. An incumbent firm may also benefit from knowledge spillover and investment in R\&D (Denicolai et al. 2016) to avoid the so-called "competency trap". Our finding also suggests that managers in incumbent firms should be cautious when deciding whether to invest in knowledge or source it from external partners. This choice may be conditional on i) absorptive capacity of the incumbent firm; ii) market competition iii) protection of intellectual property iv) public policy to support innovation and entrepreneurship.

\section{Limitations and Further research.}

Our findings call for further analysis of KSTE in innovation across firms with different levels of cognitive, institutional, and geographical proximities to their partners.

Given the significant differences in KSTE between start-ups and incumbents, other forms of knowledge collaboration with external partners should be explored, including uncertainty and risk, such as collaboration created for knowledge producer and knowledge recipient.

In doing so, further research will bring together the open innovation and knowledge transfer literature to explain the breadth and depth of knowledge spillover related to the 
intensity of knowledge spillovers as well as the number of knowledge partners and sources of knowledge that could potentially be exploited by entrepreneurs to create new to market products.

The main limitations of this study are as follows. Firstly, due to the UK Innovation Survey's anonymous nature, no additional sources for information on external partners and sources of knowledge could be added, neither the location of knowledge (regional, national, overseas). These could have been used to supplement our knowledge with new evidence.

Secondly, this research focuses specifically on innovative start-ups vs. incumbents within one country. A new cross-country study could measure differences in institutions and regional characteristics, which may, directly and indirectly, affect innovation. We were also unable to measure the firm's amount of research to access external knowledge via open innovation channels.

Open Access This article is licensed under a Creative Commons Attribution 4.0 International License, which permits use, sharing, adaptation, distribution and reproduction in any medium or format, as long as you give appropriate credit to the original author(s) and the source, provide a link to the Creative Commons licence, and indicate if changes were made. The images or other third party material in this article are included in the article's Creative Commons licence, unless indicated otherwise in a credit line to the material. If material is not included in the article's Creative Commons licence and your intended use is not permitted by statutory regulation or exceeds the permitted use, you will need to obtain permission directly from the copyright holder. To view a copy of this licence, visit http://creativecommons.org/licenses/by/4.0/.

\section{References}

Acs, Z. J., \& Audretsch, D. B. (1990). Innovation and small firms. Mit Press.

Acs, Z. J., Braunerhjelm, P., Audretsch, D. B., \& Carlsson, B. (2009). The knowledge spillover theory of entrepreneurship. Small Business Economics, 32(1), 15-30.

Acs, Z. J., \& Szerb, L. (2007). Entrepreneurship, economic growth and public policy. Small business economics, 28(2-3), 109-122.

Acs, Z. J., \& Varga, A. (2005). Entrepreneurship, agglomeration and technological change. Small business economics, 24(3), 323-334.

Agarwal, R., Audretsch, D., \& Sarkar, M. B. (2007). The process of creative construction: knowledge spillovers, entrepreneurship, and economic growth. Strategic Entrepreneurship Journal, 1(3-4), 263-286.

Agarwal, R., Audretsch, D., \& Sarkar, M. B. (2010). Knowledge spillovers and strategic entrepreneurship. Strategic Entrepreneurship Journal, 4(4), 271-283.

Anselin, L., Varga, A., \& Acs, Z. (1997). Local geographic spillovers between university research and high technology innovations. Journal of urban economics, 42(3), 422-448.

Arora, A., Athreye, S., \& Huang, C. (2016). The paradox of openness revisited: Collaborative innovation and patenting by UK innovators. Research Policy, 45(7), 1352-1361.

Arrow K. (1962). Economic welfare and the allocation of resources for invention. In: Nelson, R. (Eds.). The Rate and Direction of Inventive Activity. Princeton University Press, Princeton.

Audretsch, D. B. (2014). From the entrepreneurial university to the university for the entrepreneurial society. The Journal of Technology Transfer, 39(3), 313-321.

Audretsch, D. B., \& Belitski, M. (2013). The missing pillar: The creativity theory of knowledge spillover entrepreneurship. Small Business Economics, 41(4), 819-836.

Audretsch, D. B., \& Belitski, M. (2019). Science Parks and Business Incubation in the United Kingdom: Evidence from University Spin-Offs and Staff Start-Ups. In Science and Technology Parks and Regional Economic Development (pp. 99-122). Palgrave Macmillan, Cham.

Audretsch, D. B., \& Belitski, M. (2020a). The limits to collaboration across four of the most innovative UK industries. British Journal of Management, 31(4), 830-855.

Audretsch, D. B., \& Belitski, M. (2020b). The role of R\&D and knowledge spillovers in innovation and productivity. European Economic Review, 123, 103391. 
Audretsch, D. B., Belitski, M., Caiazza, R., \& Lehmann, E. E. (2020). Knowledge management and entrepreneurship. International Entrepreneurship and Management Journal, 1-13.

Audretsch, D. B., Belitski, M., \& Desai, S. (2015). Entrepreneurship and economic development in cities. The Annals of Regional Science, 55(1), 33-60.

Audretsch, D., \& Caiazza, R. (2016). Technology transfer and entrepreneurship: cross-national analysis. The Journal of Technology Transfer, 41(6), 1247-1259.

Audretsch, D. B., \& Feldman, M. P. (1996). R\&D spillovers and the geography of innovation and production. The American economic review, 86(3), 630-640.

Audretsch, D. B., \& Keilbach, M. (2007). The theory of knowledge spillover entrepreneurship. Journal of Management Studies, 44(7), 1242-1254.

Audretsch, D. B., \& Keilbach, M. (2008). Resolving the knowledge paradox: Knowledge-spillover entrepreneurship and economic growth. Research Policy, 37(10), 1697-1705.

Audretsch, D. B., Keilbach, M. C., \& Lehmann, E. E. (2006). Entrepreneurship and economic growth. Oxford University Press.

Audretsch, D. B., \& Lehmann, E. E. (2005). Does the knowledge spillover theory of entrepreneurship hold for regions? Research Policy, 34(8), 1191-1202.

Audretsch, D. B., \& Link, A. N. (2019). Entrepreneurship and knowledge spillovers from the public sector. International Entrepreneurship and Management Journal, 15(1), 195-208.

Audretsch, D. B., \& Link, A. N. (2019). The fountain of knowledge: an epistemological perspective on the growth of US SBIR-funded firms. International Entrepreneurship and Management Journal, 15(4), 1103-1113.

Audretsch, D. B., \& Link, A. N. (2019a). Sources of knowledge and entrepreneurial behavior. University of Toronto Press.

Audretsch, D. B., Link, A. N., \& van Hasselt, M. (2019). Knowledge begets knowledge: university knowledge spillovers and the output of scientific papers from US Small Business Innovation Research (SBIR) projects. Scientometrics, 121(3), 1367-1383.

Baker, W. E., Grinstein, A., \& Harmancioglu, N. (2016). Whose innovation performance benefits more from external networks: entrepreneurial or conservative firms? Journal of Product Innovation Management, 33(1), 104-120.

Baumol, W. J. (1993). Formal entrepreneurship theory in economics: Existence and bounds. Journal of business venturing, 8(3), 197-210.

Belitski, M. (2019). Innovation in Schumpeterian-type Firms: Knowledge Collaboration or Knowledge Spillover? Foundations and Trends ${ }^{\circledR}$ in Entrepreneurship, 15(4-5), 367-389.

Belitski, M., Caiazza, R., \& Lehmann, E. E. (2019). Knowledge frontiers and boundaries in entrepreneurship research. Small Business Economics, 1-11.

Block, J. H., Thurik, R., \& Zhou, H. (2013). What turns knowledge into innovative products? The role of entrepreneurship and knowledge spillovers. Journal of Evolutionary Economics, 23(4), 693-718.

Bloom, N., Schankerman, M., \& Van Reenen, J. (2013). Identifying technology spillovers and product market rivalry. Econometrica, 81(4), 1347-1393.

Bradley, S. W., McMullen, J. S., Artz, K., \& Simiyu, E. M. (2012). Capital is not enough: Innovation in developing economies. Journal of Management Studies, 49(4), 684-717.

Braunerhjelm, P., Acs, Z. J., Audretsch, D. B., \& Carlsson, B. (2010). The missing link: knowledge diffusion and entrepreneurship in endogenous growth. Small Business Economics, 34(2), 105-125.

Braunerhjelm, P., Ding, D., \& Thulin, P. (2018). The knowledge spillover theory of intrapreneurship. Small business economics, 51(1), 1-30.

Caiazza, R., Belitski, M., \& Audretsch, D. B. (2020). From latent to emergent entrepreneurship: the knowledge spillover construction circle. The Journal of Technology Transfer, 45(3), 694-704.

Cassiman, B., \& Veugelers, R. (2002). R\&D cooperation and spillovers: some empirical evidence from Belgium. American Economic Review, 92(4), 1169-1184.

Chen, C., Link, A. N., \& Oliver, Z. T. (2018). US federal laboratories and their research partners: a quantitative case study. Scientometrics, 115(1), 501-517.

Chowdhury, F., Audretsch, D. B., \& Belitski, M. (2019). Institutions and entrepreneurship quality. Entrepreneurship Theory and Practice, 43(1), 51-81.

Cohen, W. M., \& Levinthal, D. A. (1989). Innovation and learning: the two faces of R \& D. The economic journal, 99(397), 569-596.

Delmar, F., Wennberg, K., \& Hellerstedt, K. (2011). Endogenous growth through knowledge spillovers in entrepreneurship: an empirical test. Strategic Entrepreneurship Journal, 5(3), 199-226.

Denicolai, S., Ramirez, M., \& Tidd, J. (2016). Overcoming the false dichotomy between internal R\&D and external knowledge acquisition: Absorptive capacity dynamics over time. Technological Forecasting and Social Change, 104, 57-65. 
Eckhardt, J. T., Ciuchta, M. P., \& Carpenter, M. (2018). Open innovation, information, and entrepreneurship within platform ecosystems. Strategic entrepreneurship journal, 12(3), 369-391.

Estrin, S., Korosteleva, J., \& Mickiewicz, T. (2020). Schumpeterian entry: innovation, exporting, and growth aspirations of entrepreneurs. Entrepreneurship: Theory and Practice.

Foss, N. J., Klein, P. G., Kor, Y. Y., \& Mahoney, J. T. (2008). Entrepreneurship, subjectivism, and the resource-based view: toward a new synthesis. Strategic Entrepreneurship Journal, 2(1), 73-94.

Fritsch, M., \& Wyrwich, M. (2018). Regional knowledge, entrepreneurial culture, and innovative start-ups over time and space-an empirical investigation. Small Business Economics, 51(2), 337-353.

Giovannetti, E., \& Piga, C. A. (2017). The contrasting effects of active and passive cooperation on innovation and productivity: Evidence from British local innovation networks. International Journal of Production Economics, 187, 102-112.

Hall, B., Helmers, C., Rogers, M., \& M., \& Sena, V. . (2013). The importance (or not) of patents to UK firms. Oxford Economic Papers, 65(3), 603-629.

Jaffe, A. B., Trajtenberg, M., \& Henderson, R. (1993). Geographic localization of knowledge spillovers as evidenced by patent citations. The Quarterly journal of Economics, 108(3), 577-598.

Keller, W. (2002). Geographic localization of international technology diffusion. The American Economic Review, 92(1), 120-142.

Ketchen, D. J., Jr., Ireland, R. D., \& Snow, C. C. (2007). Strategic entrepreneurship, collaborative innovation, and wealth creation. Strategic entrepreneurship journal, 1(3-4), 371-385.

Khalil, S., \& Belitski, M. (2020). Dynamic capabilities for firm performance under the information technology governance framework. European Business Review.

Kihlstrom, R. E., \& Laffont, J. J. (1979). A general equilibrium entrepreneurial theory of firm formation based on risk aversion. Journal of political economy, 87(4), 719-748.

Leiponen, A., \& Helfat, C. E. (2010). Innovation objectives, knowledge sources, and the benefits of breadth. Strategic Management Journal, 31, 224-236.

Link, A. N., Morris, C. A., \& van Hasselt, M. (2019). The impact of public R\&D investments on patenting activity: technology transfer at the US Environmental Protection Agency. Economics of Innovation and New Technology, 28(5), 536-546.

Link, A. N., \& Oliver, Z. T. (2020). Technology Transfer and US Public Sector Innovation. Edward Elgar Publishing.

Link, A. N., \& Rees, J. (1990). Firm size, university-based research, and the returns to R\&D. Small business economics, 2(1), 25-31.

Link, A. N., \& Scott, J. T. (2011). The Theory and Practice of Public-Sector R\&D Economic Impact Analysis: The Case of the National Institute of Standards and Technology (No. 11-16). University of North Carolina at Greensboro, Department of Economics.

Link, A. N., \& Scott, J. T. (2019). Technological change in the production of new scientific knowledge: a second look. Economics of Innovation and New Technology, 1-11.

Link, A. N., \& Scott, J. T. (2020). Creativity-enhancing technological change in the production of scientific knowledge. Economics of Innovation and New Technology, 29(5), 489-500.

Marshall, A. (1890). Principles of economics. London: Macmillan.

Nason, R. S., Wiklund, J., McKelvie, A., Hitt, M., \& Yu, W. (2019). Orchestrating boundaries: The effect of R\&D boundary permeability on new venture growth. Journal of Business Venturing, 34(1), 63-79.

Newbert, S. L., \& Tornikoski, E. T. (2013). Resource acquisition in the emergence phase: Considering the effects of embeddedness and resource dependence. Entrepreneurship Theory and Practice, 37(2), 249-280.

Office for National Statistics. (2017a). UK Innovation Survey, 1994-2016: Secure Access. [data collection]. 6th Edition. UK Data Service. SN: 6699, http://doi.org/https://doi.org/10.5255/UKDA-SN-6699-6.

Office for National Statistics. (2017b). Business Structure Database, 1997-2017: Secure Access. [data collection]. 9th Edition. UK Data Service. SN: 6697, http://doi.org/https://doi.org/10.5255/ UKDA-SN-6697-9

Romer, P. M. (1986). Increasing returns and long-run growth. Journal of Political Economy, 94, 1002-1037.

Roper, S., Love, J. H., \& Bonner, K. (2017). Firms' knowledge search and local knowledge externalities in innovation performance. Research Policy, 46(1), 43-56.

Santamaria, L., Nieto, M. J., \& Barge-Gil, A. (2009). Beyond formal R\&D: Taking advantage of other sources of innovation in low-and medium-technology industries. Research Policy, 38(3), 507-517.

Sauermann, H. (2018). Fire in the belly? Employee motives and innovative performance in start-ups versus established firms. Strategic Entrepreneurship Journal, 12(4), 423-454.

Shane, S., \& Venkataraman, S. (2000). The promise of entrepreneurship as a field of research. Academy of Management Review, 25(1), 217-226. 
Short, J. C., Moss, T. W., \& Lumpkin, G. T. (2009). Research in social entrepreneurship: Past contributions and future opportunities. Strategic entrepreneurship journal, 3(2), 161-194.

Shu, C., Liu, C., Gao, S., \& Shanley, M. (2014). The knowledge spillover theory of entrepreneurship in alliances. Entrepreneurship Theory and Practice, 38(4), 913-940.

Spithoven, A., Clarysse, B., \& Knockaert, M. (2010). Building absorptive capacity to organise inbound open innovation in traditional industries. Technovation, 30(2), 130-141.

Toms, S., Wilson, N., \& Wright, M. (2020). Innovation, intermediation, and the nature of entrepreneurship: A historical perspective. Strategic Entrepreneurship Journal, 14(1), 105-121.

Van Beers, C., \& Zand, F. (2014). R\&D cooperation, partner diversity, and innovation performance: an empirical analysis. Journal of Product Innovation Management, 31(2), 292-312.

Van Stel, A., Carree, M., \& Thurik, R. (2005). The effect of entrepreneurial activity on national economic growth. Small business economics, 24(3), 311-321.

West, J., \& Bogers, M. (2014). Leveraging external sources of innovation: a review of research on open innovation. Journal of Product Innovation Management, 31(4), 814-831.

Wooldridge, J. M. (2009). Introductory Econometrics: A Modern Approach (4th ed.). Mason, OH: South-Western.

Zahra, S. A. (1996). Technology strategy and new venture performance: A study of corporate sponsored and independent biotechnology ventures. Journal of Business Venturing, 11, 289-321.

Publisher's Note Springer Nature remains neutral with regard to jurisdictional claims in published maps and institutional affiliations. 